\title{
A Comparative Study on Regular Students' Sensitivity at the Inclusive Education of Junior High School and Senior High School in Surakarta
}

\author{
Arozi Setiawan, Abdul Salim, Sunardi \\ Universitas Sebelas Maret, Indonesia \\ E-mail: Arozisetiawan@gmail.com
}

\begin{abstract}
Sensitivity is an ability to understanding an individual which is implemented into knowledge, attitude, and behavior. This study is aimed to know the level of regular students' sensitivity at the inclusive education in the level education of Junior High School and Senior High School. The subjects of this research are the students of Junior High School and Senior High School, each of them is 45 students. The technique of collecting the data uses questionnaire. The technique of analyzing the data uses the normality test, homogeneity test, and independent t-test. The result of this research shows that the distribution of the data is normal, homogeny and the average of sensitivity value's regular students at the level of Junior High Schoo is 127.98, while the average of sensitivity value's regular students at the level of Senior High School is 133.89 . Based on the result, it can be concluded that regular students' sensitivity toward the children with special needs at the Senior High School is higher than Junior High School.
\end{abstract}

Keywords: sensitivity, inclusive education, regular student, children with special needs.

\section{INTRODUCTION}

Inclusive education is an alternative to fulfill the needs of children with special needs toward disability that he or she bears (Florian, 2008). Social and academic development of children with special needs in making friendly environment and not discriminate where they can participate in joint activity are in inclusive education (Lundqvist, et al., 2015). Therefore, nowadays education placement in Indonesia was changed from mainstreaming to inclusive, so inclusive education is established as the government's purpose to fulfill the needs of children with special needs (Evitasari \& Lestari, 2017). Darma \& Rusyidi (2016) said that inclusive education is a manifestation the equivalence of education without discrimination where the children with special needs can get equal education in the regular class with their friends. Inclusive education in Indonesia has been mentioned in Peraturan Pemerintah No. 70 Tahun 2009 (Regulation Government Number 70 Year of 2009) about Pendidikan Inklusif Bagi Peserta Didik Yang Memiliki Kelainan Dan Memiliki Potensi Kecerdasan Dan/Atau Bakat Istimewa (Inclusive education for the disability students and having special intelligence), the first article mentions "inclusive education is a system of education which gives chance for all students who have certain disability and special skill or intelligence to get similar education or learning as the normal student generally". Thus, in the implementation of inclusive education in Indonesia refers to Peraturan Pemerintah No. 70 Tahun 2009 (Regulation Government Number 70 Year of 2009), where the children with special needs have education and service which is suitable with their needs in the inclusive education (Martika \& Salim, 2017.
Inclusive education is the answer of pessimist point of view toward children with special needs, where the peer is the setting to reach equality and participation in inclusive education (Fitriana \& Sulthoni, 2017). Peer's positive support, self-esteem support, increasing of academics and social work are the positive impacts of inclusive (Flem \& Keller, 2000). Related to children with special needs, they are the icon which is pointed for a student who needs help based on his ability or disability in order to improve their potency, where they need also to interact with others, such peers of students with special needs or regular students (Diahwati, Hariyono, \& Hanurawan, 2016). In that interaction, normal children are learned to care with other children's needs and having tolerant toward children with special needs and shaped the children with the higher empathy than children who never mingle with children with special (Kusumastuti, Yusuf, \& Himawanto, 2017).

In social inclusive, we are ready to change and adjust the system, environment, and activities related to all people and also considering people's needs, where it is not only disabilities children who have to adjust their self among the set, so these need sensitivity. Talking about sensitivity, this tends to social sensitivity. Lohman, Zenger, \& Weschler (2015) say that social sensitivity is the ability to sense how others think and feel, and of behavioral flexibility i. e., the ability to act appropriately on the basis of these understandings. The sensitivity of children with special needs includes positive act and empathy (Foley et al., 2007). The aspects of sensitivity are the understanding ability which is related to understanding, responding, and express in the act (Kusumastuti, 2017). 
Table 1. Score of Regular Students' Sensitivity at SMP

\begin{tabular}{cccccccccc}
\hline Subject & Score & Subject & Score & Subject & Score & Subject & Score & Subject & Score \\
\hline 1 & 126 & 11 & 130 & 21 & 125 & 31 & 112 & 41 & 115 \\
2 & 123 & 12 & 128 & 22 & 118 & 32 & 125 & 42 & 132 \\
3 & 141 & 13 & 112 & 23 & 128 & 33 & 122 & 43 & 120 \\
4 & 133 & 14 & 137 & 24 & 115 & 34 & 136 & 44 & 145 \\
5 & 142 & 15 & 133 & 25 & 136 & 35 & 120 & 45 & 140 \\
6 & 147 & 16 & 121 & 26 & 133 & 36 & 131 & & \\
7 & 127 & 17 & 126 & 27 & 128 & 37 & 145 & & \\
8 & 134 & 18 & 123 & 28 & 115 & 38 & 129 & & \\
9 & 129 & 19 & 116 & 29 & 141 & 39 & 126 & & \\
10 & 112 & 20 & 102 & 30 & 139 & 40 & 141 & & \\
\hline
\end{tabular}

Table 2. Score of Regular Students' Sensitivity at SMA

\begin{tabular}{cccccccccc}
\hline Subject & Score & Subject & Score & Subject & Score & Subject & Score & Subject & Score \\
\hline 1 & 120 & 11 & 120 & 21 & 155 & 31 & 141 & 41 & 137 \\
2 & 117 & 12 & 119 & 22 & 157 & 32 & 136 & 42 & 139 \\
3 & 165 & 13 & 128 & 23 & 136 & 33 & 116 & 43 & 137 \\
4 & 130 & 14 & 118 & 24 & 119 & 34 & 153 & 44 & 155 \\
5 & 125 & 15 & 130 & 25 & 134 & 35 & 139 & 45 & 126 \\
6 & 139 & 16 & 130 & 26 & 128 & 36 & 124 & & \\
7 & 114 & 17 & 137 & 27 & 141 & 37 & 135 & & \\
8 & 118 & 18 & 131 & 28 & 146 & 38 & 143 & & \\
9 & 116 & 19 & 132 & 29 & 144 & 39 & 134 & & \\
10 & 124 & 20 & 145 & 30 & 134 & 40 & 158 & & \\
\hline
\end{tabular}

The research related to regular students' sensitivity at the inclusive education was done by Wibowo \& Anjar (2015) concluded that children with special needs Tunadaksa did not experience difficulty when socializing with classmates, they can be accepted well by their friends. It means that regular students have been empathy or being sensitive toward children with special needs to study together in the classroom. The next study was conducted by Hadjar (2010) is about regular students' empathy at the SMP (junior high school) showed revealed that regular students' empathy toward children with special needs were high. Other research was done by Yudhanto (2016) was about regular students' social interaction with the children with special needs at the level education of SMA (senior high school), one of the result was in the nonacademic activity, non-disabilities students always help disabilities students to guide them for a just go to the canteen, mosque, bathroom, library, and also teacher's office. Based on the several previous studies, it can be concluded that the level of regular students' sensitivity toward children with special needs at the inclusive education of SMP and SMA has been good.

Therefore, this research purposed to compare the level of regular students' sensitivity toward the children with special needs at the inclusive education of SMP and SMA in Surakarta which has been the city of inclusive, and the result can be used to the develop the next study related to sensitivity at the inclusive education.

\section{METHOD}

The method of this research uses comparative method. Comparative means "comparison". According to Purwanto (2010), a comparative study is a research which compares between two or more groups in a variable. The method used is a comparative study. By using comparative method, the data are compared and can be concluded.

The subject of this research is the regular students of inclusive education in Surakarta at SMP and SMA, each of them consists of 45 students. The data are collected by sensitivity questionnaires which consist of three aspects of knowledge, attitude, and acts of the research of Kusumastuti (2017). Reliability of measurement uses Cronbach Alpa's measurement reliability with the trustworthiness of the knowledge aspect is 0.965 , the attitude aspect is 0.826 , and acts aspect is 0.934 . The data are analyzed by the normality test, the homogeneity test, and T-independent test with SPSS 23.

\section{FINDINGS AND DISCUSSION}

\section{Finding}

The results of the data of regular students' sensitivity toward children with special needs at inclusive education presented in the table 1 and 2 . 
Table 3. Normality Test, One-Sample KolmogorovSmirnov Test

\begin{tabular}{llcc}
\hline & & $\begin{array}{c}\text { Junior High } \\
\text { School }\end{array}$ & $\begin{array}{c}\text { Senior High } \\
\text { School }\end{array}$ \\
\hline $\mathrm{N}$ & 45 & 45 \\
\hline Normal & Mean & 127,98 & 133,89 \\
Parameters ${ }^{\mathrm{a}, \mathrm{b}}$ & Std. & 10,387 & 12,732 \\
& Deviation & &, 085 \\
\hline Most Extreme & Absolute &, 056 &, 085 \\
Differences & Positive &, 053 &,- 067 \\
& Negative &,- 056 &, 085 \\
Test Statistic & &, 056 &, 200 \\
Asymp. Sig. (2-tailed) &, 200 & \\
\hline
\end{tabular}

a. Test distribution is Normal.

b. Calculated from data.
Table 4. Homogeneity test

\begin{tabular}{cccc}
\hline \multicolumn{4}{c}{ Test of Homogeneity of Variances } \\
\hline \multicolumn{4}{c}{ Score } \\
\hline Levene Statistic & df1 & df 2 & Sig. \\
\hline 1,493 & 1 & 88 &, 225 \\
\hline
\end{tabular}

Table 6. Descriptive Statistics

\begin{tabular}{lccc}
\hline & N & Mean & Std. Deviation \\
\hline SMP & 45 & 127,98 & 10,387 \\
SMA & 45 & 133,89 & 12,732 \\
\hline
\end{tabular}

Table 5. Independent Samples Test

\begin{tabular}{|c|c|c|c|c|c|c|c|c|c|c|}
\hline & \multirow{3}{*}{$\mathrm{F}$} & \multicolumn{3}{|c|}{$\begin{array}{c}\text { Levene's Test } \\
\text { for Equality of } \\
\text { Variances }\end{array}$} & \multicolumn{5}{|c|}{ t-test for Equality of Means } & \\
\hline & & \multirow[t]{2}{*}{ Sig. } & \multirow[t]{2}{*}{$\mathrm{t}$} & \multirow[t]{2}{*}{ df } & \multirow{2}{*}{$\begin{array}{c}\text { Sig. } \\
\text { (2-tailed) }\end{array}$} & \multirow{2}{*}{$\begin{array}{c}\text { Mean } \\
\text { Differ- } \\
\text { ence }\end{array}$} & \multirow{2}{*}{$\begin{array}{l}\text { Std. Error } \\
\text { Differ- } \\
\text { ence }\end{array}$} & \multicolumn{2}{|c|}{$\begin{array}{c}\text { 95\% Confidence Interval } \\
\text { of the Difference }\end{array}$} & \\
\hline & & & & & & & & Lower & Upper & \\
\hline \multirow[t]{2}{*}{ Score } & $\begin{array}{l}\text { Equal variances } \\
\text { assumed }\end{array}$ & 1,493 & ,225 & $-2,413$ & 88 &, 018 & $-5,911$ & 2,449 & $-10,779$ & $-1,043$ \\
\hline & $\begin{array}{l}\text { Equal variances } \\
\text { not assumed }\end{array}$ & & & $-2,413$ & 84,589 &, 018 & $-5,911$ & 2,449 & $-10,782$ & $-1,041$ \\
\hline
\end{tabular}

Figure 1. Diagram of regular students' Sensitivity at the $S M P$ and $S M A$

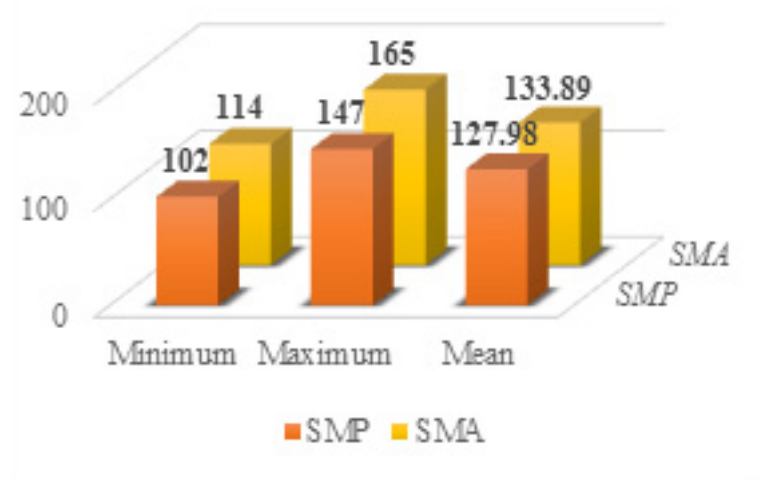

Normality Test

Normality test is used to know whether normal or not about distribution of the data on variable research. The results of the normality test by using Kolmogorov-Smirnov are presented in table 3. Based on the normality test in table 3 by using KolmogorovSmirnov, the result was sig value. The data at the SMP and SMA were $0.200(0.200>0.05)$. It means that the data of SMP and SMA are the normal distribution.

\section{Homogeneity Test}

Homogeneity test is used to know the variation of the variable score for the research subject, whether it is homogeny or not. The results of the homogeneity test are presented in table 4 . Based on the table 4 , it can be known that the result of the homogeneity test shows significant value is 0.225 . Because $p=0.225>$ 0.05 , can be concluded that variation of the data are homogeny.

\section{Independent T-test}

Independent T-test is used to compare both of the sample averages, whether it is similar or different. The result of Independent T-test about regular students' sensitivity at SMP and SMA are presented in table 5 . Based on the table 5, it can be seen sig. value (2-tailed) is $0.018<0.05$. It means that there is between difference between the average score of regular students' sensitivity toward the children with special needs at inclusive education of SMP and SMA. The statistics of the both group are presented in table 6 .

Based on the table 6 , it can be seen sig. value (2-tailed) is $0.018<0.05$. It means that there is the difference between the average score of regular students' sensitivity toward the children with special needs at the inclusive education of SMP and SMA. The statistics of both groups are presented in figure 1 . 


\section{Discussion}

Based on the research findings, the regular students' sensitivity to inclusive education at the level of SMA was better with the average value 127,98 than at the level of SMP with the average value 133,89 . Despite the sensitivity value of SMP was lower than SMA, it did not mean that the sensitivity was low so. The level of sensitivity at SMP was good, but better sensitivity was at the level education of SMA. As the research of Hadjar (2010) that regular students' empathy was running from 55 students with the percentage $56,7 \%$, low classification of 42 students with the percentage $43,3 \%$ so regular students' empathy could be concluded. It revealed that regular students at the level of education of SMP in caring, empathy has been good.

Despite the difference in average values was not much, but the sensitivity of regular students in inclusive education must be increased. It needed the collaboration of the school to conduct learning activity such as peer teaching, cooperative learning, training in order the ability of regular students' caring toward children with special needs in the class can be better. The resulting study of Kusumastuti, Yusuf, \& Himawanto (2017) was about awareness training for the children with special needs toward regular students in inclusive education such there were many regular students who ever help them with the resulting study was shown by $60 \%$, the superiority and challenges of children with special needs have not known by regular students. It could be seen by students with special needs who knew how the regular students treat them was only $50,83 \%$.

These were facts that actually regular students have had the caring ability for the children with special needs in inclusive education where many regular students have helped them. But, it was not optimally caused by lack of regular students' caring about the superiority and challenges which were faced by children with special needs, so that regular student could not understand them well. Therefore, the teenagers of regular students were lack of social ability and their knowledge related to other people. People who have higher social ability could concern more, helpful, and empathy (Hazadiyah, 2013). Likewise, the good or not the sensitivity of regular students toward children with special needs at the level education of junior high school and senior high school in inclusive education depend on the social ability of regular students in inclusive education.

\section{CONCLUSION}

Based on the research, it can be concluded that average value of regular students' sensitivity toward the children with special needs at the level education of
SMA (senior high school) was higher than at the level education of SMP (junior high school).

It is better for the school to give the program for the regular students in inclusive education to increase regular students' sensitivity toward the children with special needs. Regular students at the inclusive education can be a source of information and motivation for the children with special needs. In every event, the school must provide cooperative peers for the regular students and children with special needs, so the sensitivity of regular students can be better. The higher sensitivity of the regular students toward children with special needs can increase self-confident of children with special needs in inclusive education, likewise, a social problem which is faced with disabilities in inclusive education can be overcome.

\section{REFERENCES}

Darma, I. P., \& Rusyidi, B. (2016). Pelaksanaan Sekolah Inklusi di Indonesia. Prosiding KS, 2(2), 223-227.

Diahwati, R., Hariyono, H., \& Hanurawan, F. (2016). Keterampilan Sosial Siswa Berkebutuhan Khusus di Sekolah Dasar Inklusi. Jurnal Pendidikan: Teori, Penelitian, dan Pengembangan, 1(8), 16121620.

Evitasari, T. S., \& Lestari, R. (2017). Hubungan Antara Dukungan Sosial Dengan Kepercayaan Diri Pada Siswa SMA Inklusi (Doctoral dissertation, Universitas Muhammadiyah Surakarta).

Fitriana, D. A., \& Sulthoni, S. (2017). Inclusive Education Implementation At Sdn Sumbersari 1 Malang. Jurnal Penelitian dan Pengembangan Pendidikan Luar Biasa, 3(1), 46-53.

Flem, A., \& Keller, C. (2000). Inclusion in Norway: a study of ideology in practice. European Journal of Special Needs Education, 15(2), 188-205.

Florian, L. (2008). Inclusion: special or inclusive education: future trends. British Journal of Special Education, 35(4), 202-208.

Foley, J. T., Tindall, D., Lieberman, L., \& Kim, S. Y. (2007). How to develop disability awareness using the sport education model. Journal of Physical Education, Recreation \& Dance, 78(9), 32-36.

Hadjar, D. (2010). Empati Siswa Reguler terhadap Siswa Berkebutuhan Khusus di Kelas Inklusi SMP Negeri 18 Malang. SKRIPSI Jurusan Bimbingan dan Konseling \& Psikologi-Fakultas Ilmu Pendidikan UM.

Hazadiyah, D. D. (2013). Hubungan Antara Kompetensi Sosial dan Kepercayaan Diri pada Siswa (Studi pada Siswa kelas X Madrasah Aliyah Negeri 2 Kota Bandung). (Doctoral dissertation, UIN Sunan Gunung Djati Bandung). 
Kusumastuti, G., Yusuf, M., \& Himawanto, D. A. (2017). The Need of Disability Awareness Training for Regular Students in Inclusive School. International Journal of Recent Engineering Science, 3(4), 15-19.

Kusumastuti, G. (2017). Pengembangan Model Pelatihan Sensitivitas terhadap Anak Berkebutuhan Khusus bagi Siswa Reguler di Sekolah Inklusi. (Doctoral dissertation, Universitas Sebelas Maret).

Lohman, K., Zenger, J. H., \& Weschler, I. R. (2015). Some perceptual changes during sensitivity training. The Journal of Educational Research, 53(1), 28-31.

Lundqvist, J., Mara, A. W., \& Siljehag, E. (2015). Inclusive Education, Support Provisions and Early Childhood Educational Pathways in the Context of Sweden: A Longitudinal Study. International Journal of Special Education, 30(3), 3-16.
Martika, T., \& Salim, A. (2017). Comparative Study of Regular Teachers' Special Education Pedagogy Competence Level in Elementary and Senior High Inclusive School. Journal of ICSAR, 1(1), 32-35.

Peraturan Pemerintah No 70 Tahun 2009 Tentang Pendidikan Inklusif Bagi Peserta Didik Yang Memiliki Kelainan Dan Memiliki Potensi Kecerdasan Dan/Atau Bakat Istimewa.

Purwanto. (2010). Metodologi Peneltian Kuantitatif Untuk Psikologi dan Pendidikan. Yogyakarta: Pustaka Pelajar

Wibowo, S. B., \& Anjar, T. (2015). Studi Kasus Pola Relasi Sosial Anak Berkebutuhan Khusus (Abk) Tuna Daksa Yang Berada Di SD Umum (Inklusi) Di Kota Metro. Jurnal SosioHumaniora, 6(1), 2223.

Yudhanto, R. (2016). Interaksi Sosial Difabel Dalam Sekolah Inklusi di SMA Negeri 8 Surakarta. (Doctoral dissertation, Universitas Sebelas Maret). 